Dorothea Alewell, Katrin Bähring, Anne Canis, Sven Hauff, Kirsten Thommes*

\title{
Outsourcing HR Functions. Development of an Explanatory Approach to Firms' (Non-Existent) Demand for Personnel Services $^{* *}$
}

This paper develops a comprehensive explanatory approach to the outsourcing of Human Resource (HR) functions and the resulting demand or non-demand for personnel services by companies (e.g., interim management, outplacement services, consulting in the field of HR management). Starting from the deficits of approaches that currently dominate the outsourcing debate (cost accounting approach, transaction cost approach, resource-based view of the firm), a modified and expanded framework to explain outsourcing HR management/functions is presented which includes other theoretical approaches as well. On the one hand, potential costs and benefits of outsourcing HR functions are systematically analysed, incorporating so far neglected aspects. On the other hand, triggers as well as situational and structural factors which potentially influence the outsourcing decision via the perceived alternatives or via the expectations that are formed concerning cost and benefits of outsourcing HR functions are also included in the analysis.

Key words: Outsourcing of HR Functions, Personnel Services

* Prof. Dr. Dorothea Alewell, SFB 580 (Friedrich-Schiller-University Jena) and University of Hamburg, Department of Economics and Business Administration, Chair of Business Administration and Human Resource Management, Von-Melle-Park 5, 20146 Hamburg, Germany, phone: +49 (0)40-42838-4022, fax: +49 (0)40-42838-6358, e-Mail: Dorothea.Alewell@uni-hamburg.de.

Katrin Bähring, e-Mail: katrin.baehring@wiwi.uni-jena.de.

Anne Canis, e-Mail: a.canis@wiwi.uni-jena.de.

Sven Hauff, e-Mail: sven.hauff@uni-hamburg.de.

Kirsten Thommes, e-Mail: kirsten.thommes@wiwi.uni-jena.de

** Article received: June 8, 2007

Revised version accepted after double blind review: September 17, 2007.

management revue, 18(3): 271-292

ISSN (print) 0935-9915, ISSN (internet) 1861-9908, (C) Rainer Hampp Verlag, www.Hampp-Verlag.de 


\section{Introduction: State of research related to HR outsourcing}

A wide spectrum of heterogeneous services comes under the heading of personnel or HR services. It ranges from temporary agency work to interim management, legal advice on labour law, HR-consulting, management-on-site, placement services, headhunting (or executive search), outplacement, wage and salary accounting and training services, right up to the external provision of complete Human Resource Management (HRM). Personnel services provide an external, market-based alternative to the internal procurement of HR functions and HR management. Thus, by analysing companies' demand for personnel services, we essentially address a HR make-or-buy decision with regard to the whole spectrum of HR functions and do not restrict the term "personnel services" to administrative or operational functions.

Research on outsourcing has a long-standing history in economic research. Building on the work of Coase in 1937, transaction cost theory nowadays serves as the central approach to the analysis of make-or-buy decisions (see, e.g., Williamson 1990; Williamson et al. 1975; Picot et al. 2003). However, classical methods of comparing operational costs and strategic management approaches - as, for example, the resourcebased view and core competence approaches - continue to be used to analyse makeor-buy decisions (Vosberg 2002; for an overview of U.S. and German studies see Mellewigt/Kabst 2003 and Matiaske/Mellewigt 2002). In this tradition, authors often argue that (production or transaction) cost differences between make-or-buy are crucial for the outsourcing decision (see, e.g., Burke/Ng 2006; Cánez et al. 2000; Walker/Weber 1984). More broadly, Grover et al. (1996) argue that important benefits of outsourcing like the ability to focus on the core business and strategic issues, the utilisation of expertise and economies of scale of the service provider, and better management of the cost structure need to be assessed against an increase in transactional cost and a decrease in flexibility.

Many early articles on outsourcing decisions focus on the IT sector (see, e.g., Aubert et al. 1996; Grover et al. 1996; Slaughter/Ang 1996; Ang/Cummings 1997; Ang/ Straub 1998; Bruch 1998; Lacity/Willcocks 1998; Poppo/Zenger 1998; Cánez et al. 2000; Klein 2004; Calmfors 2005; Jenster et al. 2005). While much of the research on outsourcing IT still focuses on the classical theoretical approaches for analysing outsourcing decisions, there is nevertheless a growing awareness of deficits and shortcomings of these approaches. Thus, some complementary approaches explaining IT outsourcing decisions have already been published. Ang and Straub (1998), for example, examine the influence of financial slack as a possible explanation for IT outsourcing. They argue that organisations that possess slack resources may enlarge the scale and scope of their operations by deploying slack resources toward building up internal IT resources. In case of low slack resources firms are likely to downsize internal IT services by selling IT assets. However, this hypothesis was not verified by their empirical findings. Slaughter and Ang (1996) argue that IT outsourcing may also be influenced by the dynamics of internal politics, the behaviour of leading companies in the IT community, which is imitated by other firms, and the cost and benefits of differing employment arrangements. Even though such modifications and additions to the classical theoretical approaches exist, they are neither very systematic nor have they been integrated into one coherent explanatory approach. 
Following the many studies on outsourcing IT, the outsourcing debate has more recently also included HR functions. However, until now, there have been comparatively few analyses of make-or-buy decisions regarding HR functions (but see Autor 2003; Belcourt 2006; Cooke et al. 2005; Gainey/Klaas 2003; Greer et al. 1999; Grund 2006; Klaas et al. 1999, 2001; Lawler 2005; Lawler et al. 2004; Meckl 1999; Matiaske/Mellewigt 2002; Mellewigt/Kabst 2003; Vosberg 2002).

Existing papers on HR outsourcing often apply the same classical approaches as the studies on IT outsourcing. Thus, the set of expected effects of outsourcing HR is often conceptualised quite narrowly. Utility differences between make-or-buy alternatives, which are not related to the protection of core competencies, and strategic resources are almost completely neglected (but see the list of benefits and risks without reference to a specific theoretical framework by Belcourt 2006). Cooke et al. (2005) thus resume their summary of research on HR outsourcing by stating that the dearth of research is in sharp contrast to the burgeoning prescriptive literature on HR outsourcing.

However, the HR make-or-buy decision is essentially one about the division of labour. The predominant question is which functions of HRM should be carried out within the firm and which should be managed across the market. Even so, the multitude of different approaches in the literature and the various positive and negative effects and consequences of the division of labour have barely been systematically included in the analysis of make-or-buy decisions (but see Alewell 2004, Alewell et al. 2007b). A comprehensive set of expected effects of different institutional designs for the external procurement of HR functions has still to be developed.

The scope and degree of outsourcing HR functions differ between companies and sectors (Cooke et al. 2005) and within companies with regard to single HR functions. On the basis of existing theoretical approaches, however, such patterns of demand often cannot be explained.

First, these patterns are frequently not supported by consistent hypotheses as to which situational or structural determinants of companies will influence the make-orbuy decisions and in what direction. ${ }^{1}$ However, a number of such structural and situational factors may have a strong impact on outsourcing decisions, for example, firm size (for some recent contributions on the relationship between firm size and HRM, see, e.g., Jack et al. 2006; Mayson/Barreth 2006; Marlow 2006). Thus, most studies do not derive hypotheses concerning differences in such patterns of outsourcing HR functions between sectors or firms with differing characteristics. Notable exceptions are the contributions of Lepak et al. 2005; Gainey/Klaas 2003 and Klaas et al. 1999, 2001. They derive hypotheses which rely mainly on transaction cost theoretic or resource dependence variables, including differences concerning the degree of uncertainty of the environment and of HR specificity as well as the frequency of demand.

1 Klein (2004) formulates a related position. He summarises empirical research on make-orbuy decisions which has been conducted on the basis of transaction cost theory and concludes that so far many relevant determinants have been neglected which characterise firm structure and firm environment as well as causal relations between outsourcing effects and make-or-buy decisions. 
Second, there may be different reasons why firms do not even consider HR outsourcing. Factors triggering such decision processes are often completely neglected in the existing studies on HR outsourcing.

Third, make or buy are often assumed to be alternatives which companies may choose for different HR functions. However, whether companies always conceive make and buy as alternatives or whether they will perceive only one single way of procuring HR functions as realisable, and thus whether they will in fact choose by weighing the expected effects of make and buy is ambiguous.

Summarising, until now not much is known about the outsourcing decision processes, e.g concerning the set of perceived alternatives, the importance of categories of effects and whether and how structural and situational characteristics of the focal firm influence the decision and by what channels. Overall, a powerful theory of outsourcing HR functions has yet to be developed. This theory should include a comprehensive framework that captures the different elements of the HR outsourcing decision process. Specifically, a broader catalogue of outsourcing effects, triggers of HRoutsourcing decisions as well as about situational and structural factors influencing the perceived set of alternatives, the expected effects of outsourcing and the weighing of these effects should be integrated into this framework. In a further step, specific hypotheses may be formulated about partial effects within the total decision process, for example hypotheses about triggers of HR-outsourcing decisions or situational and structural factors that have an impact on the set of perceived alternatives in the procurement of HR functions. Within the comprehensive framework, the scope of partial hypotheses as well as their relation to the overall demand or non-demand of HRoutsourcing by companies may be understood and evaluated much better than without such a framework.

In this paper, our aim is to make the first move: to outline the modules of an inclusive and integrative explanatory model of make-or-buy decisions in HRM which will help to reduce some of the research deficits outlined above. We draw on several theoretical approaches to develop a framework for a broad theoretical explanation of the HR-make-or-buy decision. However, in this paper we do not focus thoroughly on the second step, the formulation of specific and empirically testable hypotheses within some of the modules of the explanatory approach, but deal with this task in other papers. However, by describing the elements of the framework, we give many examples for relations between variables from which hypotheses can be derived and formulated empirically testable in the next step.

Our paper is organised as follows: In section 2, the main elements of the explanatory approach are presented in an overview, while each of the subsequent sections addresses one of these modules in more detail. Thus, section 3 deals with triggers of the make-or-buy decision. In section 4 , we reflect on the set of alternatives from which decision makers select one in the HR procurement decision, while section 5 addresses expected outsourcing effects. In section 6 , the focus is on several situational and structural factors which influence the (expected) effects of outsourcing in individual firms. Section 7 concludes with a brief outlook on further research needs. 


\section{Overview: Modules of the explanatory approach to HR outsourcing decisions}

The demand for personnel services in a firm is contingent on whether or not there exists a basic need for the procurement of HR services: Only if there is such a need, does the question of whether this should be met internally (make) or externally (buy), become a relevant issue. The basic necessity to procure HR services is often triggered by an imbalance between manpower requirements, on the one hand, and actual manpower endowment, on the other. This imbalance results from quantitative or qualitative shifts in one or both of these elements. Furthermore, outsourcing decisions might also be triggered by new internal schedules of responsibilities.

Even if such a need is acknowledged in a firm, a make-or-buy decision is only made if decision makers perceive make and buy as feasible alternatives. A number of subjective, personal characteristics of decision makers and factors relating to the firm and its environment may lead to a restriction of the set of alternatives, thereby potentially ruling out a decision in which the full set of alternative institutional designs for the procurement of HR services has been considered. Sayegh et al. (2004), for example, point out the important role emotions of the decider can play, especially in quick decision making. Besides emotions, they emphasise other human aspects of the decider that should also be taken into account, as for instance individual traits and cognitive mechanisms.

If the decision is based on more than one alternative, companies will assess and weigh the expected effects of the make-and-buy alternatives. The assessment of costs and benefits will potentially vary between companies, depending on situational and structural factors.

Chart 1 summarises the modules of our approach and gives an overview, which may be used as a "pathfinder" through the following sections.

Chart 1: Modules of the explanatory approach to the outsourcing of HR functions

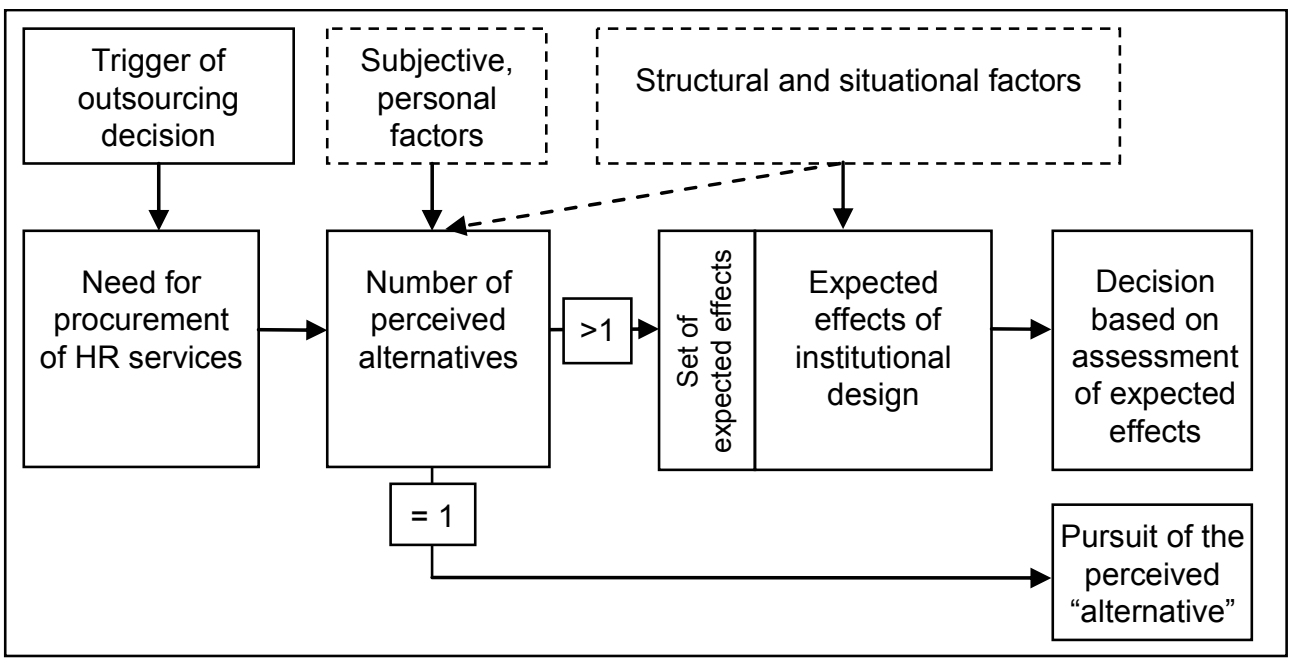




\section{Triggers of the make-or-buy decision}

One of the main tasks of HRM, besides securing the effectiveness and efficiency of $\mathrm{HR}$, is the ongoing balancing of manpower endowment and its requirements. New or changed needs for the procurement of one or more HR functions thus increase if an imbalance between manpower endowments and manpower requirements occurs. Which factors may result in such a need can be easily identified by looking at the determinants of manpower requirements and endowments:

First, manpower requirements of a firm are influenced by primary and secondary determinants (Kossbiel 1990). Primary determinants have a direct effect on manpower requirements. This group of determinants includes the range of products and services with the related kind and extent of tasks to be fulfilled in the firm, labour productivity and working time of workers per period. Changes in manpower requirements result directly from variations in these primary determinants. For example, a more comprehensive range of products and services, a decrease in labour productivity or a reduction in working time increase manpower requirements in a quantitative or qualitative manner, temporarily or permanently. Secondary determinants indirectly influence manpower requirements via changing primary determinants. They may have internal or external origins and be predictable or unpredictable for the firm. Conditions of supply and product markets, including cost structures and cost competition, a firm's production technology and organisational factors all belong to this group of determinants.

Second, changes in manpower endowment may necessitate the procurement of several HR functions. There are different factors influencing a firm's manpower endowment. On the one hand, there are more or less exogenously given parameters which a firm cannot influence directly or in a short-term perspective, for example, labour turnover, rate of absence of personnel or modifications of the manpower endowment through ageing processes. On the other hand, there are "action parameters" on which companies may decide directly, such as the procurement of personnel, staff reductions and displacement, promotions, training or further education. As for manpower requirements, an alteration of determinants of manpower endowment may be predictable or unpredictable, be caused externally or internally and take effect quantitatively or qualitatively as well as permanently or only temporarily.

Any imbalance between manpower requirements and endowment necessitates the fulfilment of several HR tasks (cf. Table 1) and may trigger a decision on whether these tasks are to be carried out by in-house production or external procurement.

Two central aspects are presented in the table. First of all, changes in manpower requirements as well as in manpower endowment are considered as triggers of the requirement of operational HR tasks. Empirical hypotheses about firms' demand for externally procured HR functions should therefore include these triggers. Furthermore, adaptation strategies which are induced by imbalances between manpower requirement and manpower endowment may result in changes in conceptual and administrative HR tasks. If, for example, the qualitative manpower requirement is greater than the qualitative manpower endowment, demand for conceptual HR tasks may result when a new personnel development strategy is needed. 
Table 1: Imbalances between manpower requirement and manpower endowment as triggers of HR tasks

\begin{tabular}{|c|c|c|c|c|}
\hline $\begin{array}{l}\text { Type of im- } \\
\text { balance }\end{array}$ & $\begin{array}{l}\text { Expected } \\
\text { duration }\end{array}$ & Examples for potential reasons & HR functions & $\begin{array}{l}\text { Potential con- } \\
\text { sequences }\end{array}$ \\
\hline \multirow[t]{2}{*}{$\begin{array}{l}\text { MR>ME } \\
\text { (ME<MR) } \\
\text { (quantitative) }\end{array}$} & temporary & $\begin{array}{l}\text { MR } \uparrow: \text { short-term influx of orders } \\
M E \downarrow: \text { absence due to illness, vacation, } \\
\text { maternity legislation }\end{array}$ & $\begin{array}{l}\text { Deployment, } \\
\text { staff recruitment }\end{array}$ & \multirow{8}{*}{ 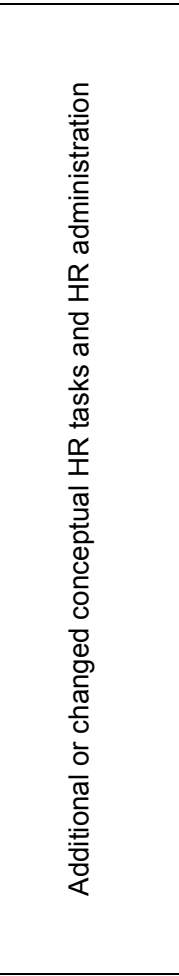 } \\
\hline & durable & $\begin{array}{l}\text { MR : diversification of product-market } \\
\text { concept } \\
\text { ME } \downarrow \text { : termination of employment, dis- } \\
\text { ability, pension, death, etc. }\end{array}$ & Staff recruitment & \\
\hline \multirow[t]{2}{*}{$\begin{array}{l}\text { MR }>\text { ME } \\
\text { (ME }<\text { MR) } \\
\text { (qualitative) }\end{array}$} & temporary & $\begin{array}{l}\mathrm{MR} \uparrow: \text { fresh need of qualifications due } \\
\text { to implementation of a new } \\
\text { product line or a new technol- } \\
\text { ogy }\end{array}$ & $\begin{array}{l}\text { Personnel devel- } \\
\text { opment, } \\
\text { staff recruitment }\end{array}$ & \\
\hline & durable & $\begin{array}{l}\mathrm{MR} \uparrow: \text { fresh/new need of qualifications } \\
\text { due to production of a new } \\
\text { product line or use of a new } \\
\text { technology }\end{array}$ & $\begin{array}{l}\text { Personnel devel- } \\
\text { opment, } \\
\text { staff recruitment }\end{array}$ & \\
\hline \multirow[t]{2}{*}{$\begin{array}{l}\text { MR }<\mathrm{ME} \\
\text { (ME>MR) } \\
\text { (quantitative) }\end{array}$} & temporary & $\begin{array}{l}\text { MR } \downarrow: \text { short-term slowdown of orders } \\
M E \uparrow: \text { miscalculation of staff recruit- } \\
\text { ment }\end{array}$ & $\begin{array}{l}\text { Deployment, } \\
\text { dismissal }\end{array}$ & \\
\hline & durable & $\begin{array}{l}\text { MR } \downarrow: \text { outsourcing of duties or depart- } \\
\text { ments, process innovation, du- } \\
\text { rable decrease of sales }\end{array}$ & Dismissal & \\
\hline \multirow{2}{*}{$\begin{array}{l}\mathrm{MR}<\mathrm{ME} \\
\text { (ME>MR) } \\
\text { (qualitative) }\end{array}$} & ${ }_{2}$ temporary & & & \\
\hline & durable & $\begin{array}{l}\text { MR } \downarrow: \text { higher productivity of existing } \\
\text { employees } \\
\text { ME } \uparrow: \text { as a result of personnel devel- } \\
\text { opment as well as through un- } \\
\text { planned learning processes or } \\
\text { further training }\end{array}$ & $\begin{array}{l}\text { Deployment, } \\
\text { dismissal }\end{array}$ & \\
\hline
\end{tabular}

$\mathrm{MR}=$ manpower requirement

$\mathrm{ME}=$ manpower endowment

Besides such imbalances, there is another group of triggers: new schedules of responsibilities, on the one hand, and new strategic decisions in HRM, on the other. Both kinds of triggers will frequently occur in combination with each other. A new HR director, for example, will often change strategic guidelines or adjust HR activities according to her or his own experiences, values and goals. In some cases, these triggers may occur isolated from each other, for example, if an economic crisis in the firm leads to readjustments of strategy without changing personnel responsibilities of HRM.

In line with our argument, Cánez et al. (2000) identify several triggers of insourcing or outsourcing decisions in general: cost reduction, lack of capacity, reduced time-

2 Temporarily higher qualitative manpower endowments are conceivable, e.g., if, due to a specific order situation, higher qualifications are available than are required for a short period of time. Because HR functions are affected only marginally, this case is not considered further in the analysis. 
to-market, increased quality, new product introduction, balance capabilities, skills shortage and increased responsiveness. As can easily be seen, these triggers stem from different areas of the decision process and HRM. Some of the triggers describe new or more concrete aims and purposes, which may have differing causes. Other triggers describe imbalances between manpower requirements and endowment. A classification of these triggers along the above lines facilitates the formulation of hypotheses.

These triggers may occur in the personnel department itself and/or in other functional departments of the firm. For example, a strong increase in manpower requirements concerning aspects of strategic marketing may result in a make-or-buy decision about contracting with a consulting firm or recruiting employees for strategic marketing. If the decision maker favours recruiting, there is a direct need for the procurement of recruiting functions, and the firm has to decide whether to assign internal staff of the personnel department to fulfil these tasks or to contract with an external service provider. Thus, triggers may exist on multiple levels in a firm.

\section{The make-or-buy decision: Generation of the set of perceived alternatives}

Imbalances between manpower requirements and manpower endowments lead to the procurement of HR tasks in the affected firm. Most HR tasks - whether they be operational, strategic or administrative - can be realised either internally by the firm itself or through external service providers. This implies that firms can be either a user or a non-user of personnel services. However, although each internal HR function theoretically has an external alternative, the make-or-buy decision depends critically on whether the decision maker observes and perceives both, the internal and the external procurement, as existent and realisable (e.g., as "real" alternatives). Apart from a set of subjective factors, there are some environmental and situational factors that may prevent any real choice between the internal realisation of HR tasks and their assignment to external service providers (cf. Chart 2).

First, knowledge about the possibilities of make or buy is the sine qua non of a perception of realisable alternatives. Only if the respective HR services and their functions are known to the decision maker, outsourcing can be taken into account. ${ }^{3}$ Second, values and attitudes of decision makers are of special relevance. For example, outsourcing of selection tasks may be prevented by personal attitudes of the manager if the internal procurement is defined as a core managing task. Or the internal procurement of HR tasks may be barred by his or her strong convictions about the superiority of external, market-based services over in-house services or by a strong orientation of decision makers to new and "modern" versus conventional HR instruments. Third, the perception of alternatives can be determined by former experiences and routines - action patterns consolidated during a process of institutionalisation - and prevent the perception of existing alternatives. This process may lead to the development of action patterns which are perceived as "objective and exterior" and, as "ready-made accounts“ (Zucker 1991: 85; Tolbert/Zucker 1996), limit the framework of action. Insti-

3 Conversely, the internal alternative may not be known, except for some rare cases, and will therefore not be included explicitly in the analysis. 
tutionalised social knowledge "makes clear what is rational in an objective sense. Other acts are meaningless, even unthinkable" (Zucker 1991: 85 et seq.). For the HR make-or-by decision this implies that even if the need for the procurement of HR services is triggered, routines in delivering HR functions may sometimes prevent a conscious outsourcing decision. This could explain differences in the perception of the set of alternatives between young, emerging companies and older firms with a higher degree of institutionalisation.

\section{Chart 2: Make or buy as perceived alternatives}

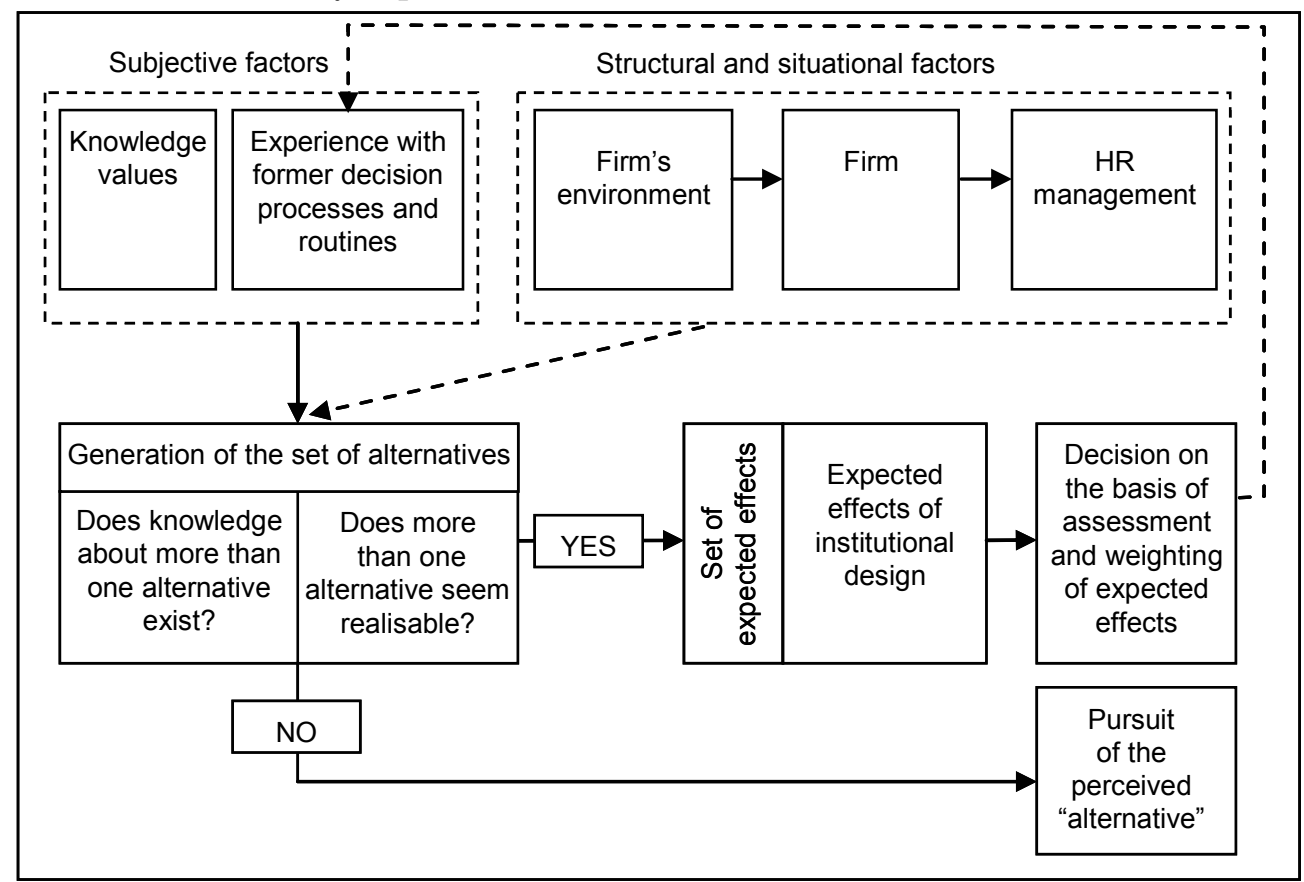

Furthermore, the extent to which an alternative appears realisable depends partly on specific structural and situational factors. Following a more macro-oriented variant of institutional theory, the "organizational field" (DiMaggio/Powell 1983) or the firm's environment may be essential factors influencing the perception of different alternatives. The behaviour of other firms, competitors or suppliers may reduce the set of perceived alternatives, characterising either make or by, but not both, as viable solutions to the HR problem. In particular, companies may adopt actions of other firms by coercion, mimetic processes and normative pressure (DiMaggio/Powell 1983), resulting in structural similarities and similar action patterns between companies. For example, a firm may use an HR service provider simply because the market leader does so, and this practice is therefore regarded as 'best practice' guaranteeing success.

Beyond these effects of institutionalisation, further influences from the companies' environment may reduce the set of perceived alternatives. One such factor is the complexity or degree of difficulty of the respective task. For example, tough competi- 
tion for employees with certain skills may cast doubt on the viability of internal recruiting. Very complex tasks reflecting firm-specific particularities may not only (as transaction cost theory contends) result in risks due to opportunism, but also in the perception that vendors will not be able to deliver the task at all. Another important factor, which is related to the aforementioned specificity, is market supply. Especially the scope, quality and price of the services vendors offer, the precise knowledge of this supply as well as the image of each HR service may be decisive. If personnel service firms have a negative image, outsourcing HR may not be conceived as a viable alternative and should be carefully weighed against internal alternatives (Lepak et al. 2005).

Regarding the firm itself, especially its size and organisational structure may affect the perception of the make-or-buy alternatives. For example, small and medium-sized companies with a flat hierarchy may have neither sufficient funds nor sufficient knowledge about the market nor explicit and formalised decision routines of deploying HR practices (see, e.g., Jack et al. 2006; Mayson/Barrett 2006; Marlow 2006; Cardon/Stevens 2004). Furthermore, the existence and activities of a works council or an in-house union or supervisory boards may prevent the perception of viable internal or external alternatives. This also goes for further temporary agency work, for example, if a works council blocks the demand for temporary agency employment, or headcount guidelines of the supervisory board exclude a recruitment of additional employees.

Finally, on the level of HR management, the resources and abilities of the personnel department as well as the roles or dominant orientation it adopts may influence the perception of alternatives (see Lepak et al. 2005 for the effect of HR orientation on the delivery of HR practices). For example, if a personnel department is not deemed capable of performing a task, the internal alternative may be regarded as not being viable without even weighing up the benefits and risks of make or buy.

Only if make and buy are indeed perceived as realisable alternatives, an assessment and weighting of the expected effects will occur. This is described in the next section.

\section{Expected effects of in-house production and external deployment in HRM}

In-house production and external procurement are different institutional designs of the provision of HR functions. The external procurement of HR services can produce different effects compared to an in-house production. ${ }^{4}$ Our focus is thus not so much on the effects of HRM itself, but on the (expected) effects of the institutional design of the HRM.

We differentiate between the effects of the institutional design on service creation, on the one hand, and - with regard to transaction cost theory - the effects of this design

In the following, we start from the assumption that the service is deployed internally and ask what effects it would have for the service to be produced externally and delivered by a vendor. Naturally, it would also be possible to look at this from the opposite perspective and ask what effects it would have for a service that was previously purchased externally to be produced internally again. 
on transaction costs, on the other hand. The effects on service creation describe the changes in costs and benefits which occur in the concrete creation of the service, especially quality effects, monetary effects, know-how related effects and stakeholder effects. ${ }^{5}$ Transaction cost effects occur in the broadest sense by entering into a contract (with an external service provider or a person assigned to perform the service internally as a newly integrated co-worker).

With regard to quality effects, the question is how differing institutional designs will impact on the quality of the required service. Quality effects could either improve or impair quality, depending on, for example, the supply conditions on the relevant market and the HR competencies of the focal firm. Positive quality effects may arise from the use of external specialists since these have a better market knowledge, a higher specialisation in specific sub-functions or a better infrastructure for the solution of specific problems. Furthermore, vendors may systematically use experiences gained from their assignments in various companies as benchmarking knowledge, thus contributing to the enforcement of best-practice solutions in the focal firm (Cooke et al. 2005; Belcourt 2006).

In addition to direct quality effects of an external deployment, the demanddriven, prompt and expedient provision of services represents a special (time-specific) dimension of quality. Thereby, the time aspect of flexibility is addressed, as the ability of companies grows to adapt to changing circumstances and variations of the demand for HR services (Foote/Folta 2002). Flexibility advantages may result if HR service providers can come up with solutions faster than the focal firm, for example because of routines they have developed, the experience-driven adaptation of less timeconsuming processes in analysing problems or because of a quicker disposal of resources. For example, temporary work agencies often maintain large databases of applicants, while many internal HR departments would have to start a new search for applicants once they have to fill a vacancy.

In the case of HR services that include the deployment of so called external staff in a firm (interim management, temporary agency work and HR consulting; see, e.g., Connelly/Gallagher 2006), these quality effects may occur on two levels. First, the period spent by external staff in the firm may serve as an extended probation period. Thus, the decision about a permanent employment will be based on better information. This may also increase temporal flexibility as a special dimension of quality. As a result, the quality of a HR function itself is improved, e.g., selection. Second, if external staff contributes other and broader experiences and qualifications than internal staff, and if there are no countervailing effects via motivation and incentives, then the quality of work performance and, accordingly, the outcomes in other areas of operation may rise.

Another group of service creation effects of the institutional design are monetary effects (Cronin et al. 2004). Through an external procurement of HR services, the firm's (expected) exposure to fixed costs may be lower. This is always the case when fixed costs (e.g., for parts of the HR department), which would be incurred in the case of

5 These benefits are often neglected in both, the cost accounting and transaction cost approaches, as both start from the premise of given services with the same effects on returns and benefits. 
continuing in-house production, can be eliminated through the external procurement of the service, or need not even be incurred in the first place. The reduction of fixed costs may lead to a reduction of risk and an increase in flexibility in terms of a better adaptability to changes in the environment, especially in small organisations. The reduction of fixed costs goes hand in hand with a cost variabilisation of HR functions if the service provider is remunerated per service unit.

Which elements of the operational cost are relevant for the firm's decision making has already been extensively documented in other papers (for a summary, see, e.g., Vosberg 2002; Alewell et al. 2005a, 2005b). The respective results show that the relevant cost elements can either rise or fall with external service procurement, depending on the specific situation of the demanding firm. Whether and under what conditions total costs per service unit decrease or increase by using an external procurement can be determined only empirically. Total costs may be reduced if the service provider can realise economies of scale, learning curve effects, advantages of specialisation or of labour costs, and if these cost advantages exceed the provider's profit mark-up. Such cost reductions are more probable if external HR services are provided for organisations with minor and infrequent demand for specific, non-discretionary separable services, as in this case comparatively high fixed costs per service unit would arise for the focal firm (Addison/Surfield 2005). However, if dependency arises between the focal firm and the provider, profit mark-ups may form a considerable element of service prices, increasing the total costs for HR functions of the focal firm under external procurement.

Furthermore, through the external delivery of particular HR services, expected but hard-to-calculate costs arising from liability for errors, legal processes, etc. may be lower (Lever 1997). Calling in a HR consultant may be beneficial for the firm in that any such costs would be lower, because it is the service provider's responsibility to observe the law in dealing with a third party in the workplace, or comply with antidiscrimination regulations in the pre-selection process. From this perspective, a highly regulated labour law can strongly support the demand for external HR services.

Another effect is that knowledge about HR costs or the cost calculation for the HR functions may improve through the external procurement of services (Jenster et al. 2005). If a compensation agreement is achieved between the service provider and the firm, the exact amount of cost will be specified. In contrast, by the internal delivery of the HR function, the amount of relevant costs will often remain unclear. Especially small and medium-sized companies with dispersed responsibilities for HR functions will often lack information about the cost of internal procurement, but gain an indication and a basis for calculating the costs of particular personnel processes by buying services from an external service provider. It should be noted though that, if this assessment is correct and some companies in fact do not have any reliable information about the cost of internal procurement of HR functions, their expectations of possible savings through outsourcing may turn out to be unfounded.

Practitioners label expected monetary and quality effects as the dominating criteria guiding make-or-buy decisions. However, whether these criteria only dominate the expectation of effects ex ante, during the decision process or the actual ex post experiences when the decision is implemented, remains an open question. Thus, ex ante 
motives for the external procurement of services and ex post experienced effects could potentially become irrelevant. Should this apply, then firms with experience in the outsourcing of HR functions may consider a much broader set of expected effects in the make-or-buy decision. For these companies, not only monetary and quality effects, but also know-how related effects, relational or stakeholder effects and transaction cost effects may be relevant.

With respect to know-how related effects, two opposite types can occur. On the one hand, an inflow of know-how may be generated through the external procurement of HR functions if the focal firm's employees observe how the service provider fulfils its job and benefits from this. The inflow of know-how may also relate to particular information about the market situation; or conditions of an efficient application of particular instruments are either intentionally or unintentionally revealed by the service providers as they carry out their work (Calmfors 2005). Service providers may be mentors for firm members, helping to improve the abilities of staff to handle specific tasks in the future. HR services which imply the assignment of external manpower may result in direct inflows of know-how through the external employees and their human capital. A substantial inflow of know-how occurs when employees of the service provider change jobs and work for the former client. Such direct inflows of know-how could partially explain why firms deploy external manpower in their organisation. However, Connelly and Gallagher (2006) cite many reasons and empirical studies that point to a number of serious problems with know-how inflow due to insider-outsider problems and lack of trust between external and internal staff.

On the other hand, an outflow of know-how from the firm to the service provider and/or the external labour force may also occur and is often a sine qua non of creating the service. A special risk is involved concerning the strategic resources of the firm, which are a source of competitive advantages (Barney 1991; Gottfredson et al. 2005; Wernerfelt 1984). Inasmuch as the HR outsourcing decision aims at long-term task sharing between firm and service provider (Bruch 1998), the outsourcing firm may lose know-how necessary for efficiently fulfilling HR functions and managing relations to HR service providers (Cooke et al. 2005). Potential difficulties in managing these relations may arise with regard to definition of tasks, service levels and quality controls. During the assignment of temporary agency workers an outflow of knowhow can be prevented by deploying them in non-critical areas of the firm only. However, interim managers and management consultants are frequently deployed in critical areas of the organisation. The potential loss of reputation if client information is divulged as well as the significance of references in the market are potential safeguards against improper outflows of know-how. Additionally, legal instruments like nondisclosure agreements or non-competition clauses may also be used.

Altogether, the expected know-how related effects depend on the qualitative and quantitative know-how already available within the firm. They also depend on the proportion of this that comes under the heading of strategic resources, the know-how that the service provider could potentially and will effectively transfer to the firm and the effectiveness of safeguards against outflows of know-how.

Relational or stakeholder effects might exist on various different levels, e.g., with regard to permanent staff (Slaughter/Ang 1996; Connelly/Gallagher 2006), applicants as 
potential employees, workers' representations like unions and work councils, shareholders, the public and last but not least customers. Depending on which group is affected, an improvement or a deterioration in their relations to the focal firm are possible results of the purchase of HR services. On the one hand, we expect the effects on the permanent staff and workers' representation to be the most important ones because the relation between employers and employees and their representatives is at the core of HR management. On the other hand, we expect the effects on other groups like shareholders, the public and customers to be strong if the personnel service involves the assignment of external staff, namely by using consulting, temporary agency work and interim management.

The employer might try to influence the employer-employees relations (Connelly/Gallagher 2006; Cooke et al. 2005) through the external procurement of HR services. On the one hand, he or she can consciously implement reference points and performance benchmarks for the activities and compensation of permanent staff by using external HR services in order to increase the pressure for better performance. By employing external staff, e.g., consultants, temporary agency workers and interim managers, the permanent workers are made aware that they are replaceable, and this could motivate them to increase their (quantitative or qualitative) performance.

On the other hand, the employer could aim to protect his or her own permanent staff from (temporal or functional) overload in peak periods. In general, by purchasing external HR services, the HR department may be unburdened. Reducing the workload in other departments may be achieved by recruiting temporary agency workers, interim managers or consultants. Additionally, the outsourcing of highly standardised and monotonous tasks could qualitatively unburden and motivate the permanent staff, allowing them to take on strategic tasks, and thus - given a corresponding preference structure - lead to positive motivational and incentive effects (Cooke et al. 2005).

However, because of the fuzziness and the multiple directions and levels involved in the interpretation of aims and effects, these might work in unintended directions or might not be perceived at all by the relevant stakeholder group. For example, the employer's intention to protect permanent staff from overload during a peak period could be misinterpreted by the employees as an intention to generate more competition and pressure. 6 Accordingly, the external procurement of HR services can have numerous positive and negative effects, even if we only consider the permanent staff.

The possible effects of the external procurement of HR services on the relations to workers' representations like unions and works councils are similarly multifaceted. On the one hand, protection of the permanent staff against peak workloads and securing best practices in HRM may be favoured by workers' representations. However, outsourcing HR functions may have other, less beneficial effects on industrial relations: For example, in a firm with a strong and uncooperative in-house union or works council, the employer could use the external procurement of HR services to decrease the size of the workers' representation by reducing the workforce through the long-term employment of temporary agency workers. Moreover, the employer may intend to dimin-

6 Other possible effects on the relation to the permanent staff are examined by Slaughter/Ang (1996). 
ish the influence of workers' representation by citing external authorities to legitimise certain actions, for example through the employment of consultants to justify difficult reorganisation steps and dismissals, to avoid co-determination rights or exert more pressure in case of compensation issues. The external procurement of HR services will affect the relations between the employer and the union or works council differently, depending on their assessment of the effects.

A firm's outsourcing of HR functions might also influence the relations with potential employees via positive or negatives changes in the firm's reputation in the labour market. On the one hand, the use of external HR services with a negative image which has been, for example, the case for temporary agency work in Germany for a long time - could damage the firm's reputation. On the other hand, the use of external HR services which are perceived as up-to-date and efficient instruments of HRM, could positively influence the firm's image as employer. A firm's low profile in the labour market or its negative employer image can result in a demand for certain HR services. In line with the previously mentioned stakeholder effects potentially twosided effects are conceivable here as well.

The external procurement of HR services might signal to shareholders an efficient handling of financial capital, the consideration of headcount, lean management, willingness to conduct reforms or a risk minimisation in liability that stems from employment law. These motives for improving the firm's image among its (potential) shareholders may be particularly relevant if, for example, the firm's orientation to shareholder value is very strong, new capital inflows are needed or the access to external capital is restricted for some reason.

Finally, outsourcing HR functions may influence the relations with further social groups, particularly customers. We expect conflicting effects concerning external staff such as temporary agency workers, interim managers and consultants. Customers might appreciate some of the potential advantages, for example, improved quality or lower costs of products and services or quicker delivery. However, at the same time they may be wary of a lower loyalty of external manpower to the focal firm as this may result in lower quality, problems with data security or in a change of responsibilities and contact persons. We know, for example, from direct communication with service providers of interim management that interim managers often have to conceal their status as external staff vis-à-vis customers of the focal firm because the latter expects negative reactions from customers to the deployment of interim managers.

Besides the effects of institutional design on service creation just described, transaction cost effects constitute a second impact category. ${ }^{7}$ This includes all aspects surrounding the conclusion of a contract (transaction) with a service provider or the staff members who contribute to the internal provision of the service. It also includes the search for (appropriate) contractual partners, the evaluation of their quality, the conclusion of the contract, the ex post monitoring of performance, the carrying out of

In the following, we do not discuss the anticipation of different transaction cost effects when a firm deploys a different number of service providers. See Bähring/Thommes (2007) for an analysis of different institutional arrangements regarding the number of vendors. 
contractual duties and, if relevant, any modifications to the contract that may become necessary in the future. In other words: transaction costs measure the overall inputs and efforts that benefited the relations between management and service provider or internal staff. In addition, all the influences considered in the transaction cost approach are fundamental to the extent of transaction costs: In particular, the specificity of the service, the frequency of its need, the uncertainty about the type, quantity and timing of the need for the service and the behaviour of contractual partners as well as the complexity of the environment. Due to space limitations, we will not repeat these - well-known - analyses here. We expect the transaction costs of the buy solution to be high if the specificity of the demanded service is high, the competition between different service providers is low, demand is infrequent and the type of the required service is uncertain. Central characteristics of services, such as intangibility, the uno-actu principle and integration of the demand side into the process of service production, may cause problems of monitoring quality. We therefore expect those transaction costs to be very important that accrue from the assessment of the service provider and the ex post control of quality. Besides ordinary instruments for signalling quality like certification, references and short-term contracts used as probation, the process of trust building is fundamental. As soon as trust building succeeds, problems of quality monitoring and control may be perceived as less important and less grave.

To sum it up, there are several potential effects firms may consider in their makeor-buy decision. The assessment and weighting of the respective effects has an influence on whether or not a firm decides for the external provision of HR functions - or to put it in other words, if it is a user or non-user of personnel services.

\section{Factors influencing the expected effects of the institutional design}

Various external and internal factors may influence the expected effects of the make-orbuy alternatives. These effects may differ between companies in terms of strength and/or direction, depending on a number of structural and situational factors. In general, there are factors which stem from the firm's global environment, the firm itself as well as from HRM. Chart 3 provides an overview of the factors analysed in this section. ${ }^{8}$

The general economic situation, as a factor of the firm's global environment, can influence the expected effects as, for example, monetary effects will be generally be weighted more heavily in a recession, whereas in a situation of prosperity the expected quality effects can be given priority. With regard to the influence of the labour market, it is assumed that firms which operate in a tight labour market will weight quality effects more heavily than, for instance, firms which recruit their staff on a labour market with high supply so that costs would be at the fore. The competitive structure in which the firm operates can also have an influence: in a polypoly, the dominant cost orientation should result in a stronger weighting of monetary effects than in other competitive situations. In a monopoly, cost effects will only have a comparatively small impact

8 The factors on the different levels partially influence one another, which means, e.g., that the determinants relating to the firm's global environment influence the firm-specific ones, whereas the latter in turn have an influence on the factors on the level of HR management. 
Chart 3: Determinants of the set of effects and of the expected effects

Firm's global environment
General economic situation
Labour market
Competitive structure
Politics
Legal regulations
Public
Customers
External HR services

Firm
Size
Structure
Economic Situation
Strategy
Stock exchange quotation
Legal form
Life cycle phase
Industry
Supervisory board
Works council
Commitment to collective
wage agreements
Employees
Outsourcing experiences
Perceived structure of firm's
tasks

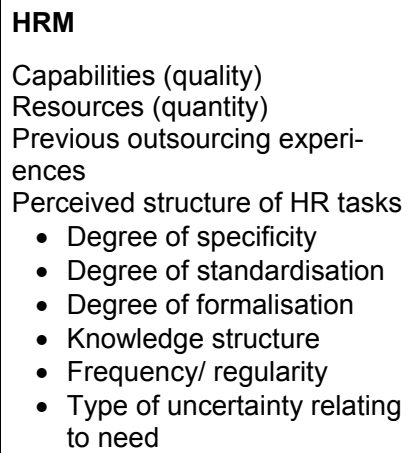

because of the market power of the monopolist. As soon as the firm faces oligopolistic market conditions (and thus an oligopolistic scope of activities), an indirect link between the evaluation of the expected effects of the HR-outsourcing decision and the firm's strategy may be relevant (see Lepak et al. 2005 ). The legal regulation of particular forms of external HR services may change the supply conditions of providers. An example are legal changes concerning temporary agency work at the beginning of 2004 in Germany, which implied a direct incentive to conclude collective wage agreements for temporary agency work and resulted in a rise in costs as well as in an improvement of the sector's reputation, leading to conflicting effects which partially underlay the legislature's aim of furthering flexible forms of work. Furthermore, the expected effects can also be influenced by the public or the firm's customers. Finally, the supply on the HR services market itself influences the effects expected by the focal companies, where knowledge about a particular service as well as its image and pricing structures ought to be especially relevant.

Another group of parameters of the outsourcing decision are the determinants related to the single firm. First of all, firm size is of importance. If small firms engage explicitly in HRM, the relative burden of fixed compared to total costs will be larger than for bigger firms because resources are often not freely dividable. Therefore, the external procurement of HR services could lower fixed costs more noticeably in small firms. Additionally, professional service providers may realise much stronger specialisation and quality advantages, compared to a one-man generalist HR department of a small firm or a large HR department with a high degree of internal specialisation. These arguments indicate that smaller firms will often expect more positive monetary and qualitative effects of an external procurement than larger firms (Adler 2003). Analogous to the influence of the economic cycle, the actual economic situation of the single firm may also influence the expected effects. Firms in a precarious economic situation may weight the expected monetary effects more strongly than firms in a more favourable economic situation. 
Firms will also weight expected effects of the external demand for HR functions differently according to their strategy. If the firm focuses on cost leadership, it will be more interested in possible cost reductions, while under a quality leadership strategy, the quality effects as well as increases and decreases in know-how will be considered as more important (if they have an impact on product quality). Furthermore, the stock exchange quotation and legal structure of the firm potentially influence the weighting of anticipated effects. If the firm is a limited liability firm quoted at the stock exchange, relations with shareholders will play an important role and be weighted heavily. Whether the firm is run by the owner or by managers could also play a role in this context. In manager-run firms, power aspects could result in a more negative assessment of the stakeholder effects than in owner-run firms, because the manager's span of control might be reduced through the outsourcing of HR services, and this could weaken managerial power. Furthermore, the legal form and related liability differences could also change the assessment of monetary liability risks in a sense that these monetary effects are weighted more heavily in firms where owners are unlimitedly liable than in firms with other liability regimes.

Additionally, the stage of the life cycle the focal firm is in can also influence the assessment and weighting of the expected effects. In the formation phase, the reduction of fixed costs is important, and thus the respective monetary effects are likely to be more heavily weighted. If an increase in know-how or knowledge about the best methods of producing HR services occurs in the external procurement of HR services, these effects would also be heavily weighted. In later phases of the life cycle, other effects will come to the fore. For example, the degree of standardisation of HRM is generally higher in the maturity and stagnation phases than in previous phases so that knowledge transfer and transaction costs decrease. Additionally, the reduction of total costs becomes increasingly important and will be weighted more heavily.

The organisational structure may also influence the weighting of the expected effects. If this structure is functionally oriented, the demand for HR services has, on the one hand, stronger relational effects with regard to the HR department, as it may increase the pressure on the existing, specialised HR department more than in other organisational structures. On the other hand, outsourcing could signal effectively in this structure that the HR department will be disburdened of peak loads and routine tasks. So a high weighting for relational effects is to be expected even though the direction of the effects is not clear ex ante. By contrast, the expectation of quality improvements could be much more positive in an object-oriented/divisional organisational structure than in a functional one, because under this condition the specialisation of the service provider will often be much stronger compared to the less specialised divisional HR department. Additionally, as in smaller firms, more positive monetary effects than in other organisational structures may arise because the service provider can exploit economies of scale.

If the firm has an active and assertive in-house union or works council, the relations with this stakeholder may be important - in contrast to companies without such a workers' representation. Additionally, the expectations of relational effects will turn out differently according to whether or not the workers' representation interprets the 
involvement of external HR services as a threat. An equivalent assessment could be valid for firms with a supervisory board including workers' representatives.

Finally, the potential expected effects of an external procurement are influenced by path-dependent characteristics and the degree of institutionalisation (David 1985; Zucker 1991; DiMaggio/Powell 1983). The firm's own preceding history of experiences with the external procurement (outsourcing) and the internal production of services as well as assessments that are well established in its institutional field presumably lead to an assessment of the importance and direction of transaction effects. With regard to transaction costs, it can be presumed that the firm's own experiences with outsourcing should lead to a more realistic assessment of the cost level and therefore to a more negative expectation of costs than if such experiences were lacking. By contrast, the firm's own experiences with service provision to others could facilitate the contract management and the assessment of potential contract partners. Mummert (2004), in a benchmarking study, demonstrates that outsourcing service providers can realise a cost saving through outsourcing of $20.9 \%$ on average. By contrast, other outsourcing firms can only realise an average cost saving of $16.9 \%$.

A third group of factors encompasses characteristics of HRM itself. The actual situation of a firm which is reflected in the resources and capabilities present in the HR department also plays an essential role with regard to the assessment of expected effects (Matiaske/Kabst 2002). In the case of deficient professionalism (Greer et al. 1999), deficient capabilities and/or deficient service quality in the firm's own HR work, possible quality effects of an external procurement of the services will presumably be more positively assessed than if the internal HR department is highly professional. Furthermore, the service provider's costs will probably be strongly perceived as additional costs which are not cancelled out by any reduction in the firm's own fixed costs, so that negative monetary effects will be perceived. If the internal HR department has taken over the role of "strategic partner of the management," then the outsourcing of standardised tasks will presumably be linked to the expectation of the removal of routine tasks and therefore produce lower costs as well as more positive motivation effects, compared to a situation where the HR department defines its role as an "administrative department" (Greer et al. 1999).

Finally, the perceived structure of HR tasks plays an important role in the assessment of expected effects. A high firm specificity of the tasks in the sense of the transaction cost approach will lead to a higher expectation of transaction costs than for generalised tasks. If the task is strongly standardised and formalised, i.e., if there is only a marginal need for adaptation of the content over time, and if there is hardly any uncertainty about the type of required services, then transaction cost problems should play a smaller role than if tasks cannot be standardised.

\section{Summary and future prospects of research}

This paper has presented a systematic and comprehensive approach to explain firms' demand and non-demand for personnel services. Important elements of this approach are the formulation of a comprehensive set of the expected effects of HR make-orbuy decisions which goes beyond the existing approaches. Other relevant elements are the systematic derivation of triggers of the HR outsourcing decision, thoughts on the 
perceived set of alternatives as well as a comprehensive list of structural and situational factors that may influence the perception of expected impacts of outsourcing HR functions or the set of alternatives considered in the decision process.

This comprehensive approach may help to reduce various deficits that have so far dominated the existing literature. First, we treat all the different personnel services together since they are all external market equivalents to internally produced HR functions. Second, we do not neglect the (non-)existence of triggers of the HRoutsourcing decision. Third, we reduce deficits concerning the narrow concentration on cost and quality effects by also regarding know-how and stakeholder effects. And finally, we also consider the relevant structural and situational factors which influence the triggering of decisions, the perceived set of alternatives and the weighing of expected effects on the demand or non-demand for HR services on different levels within the company.

The next steps should aim at a systematic formulation of hypotheses within this framework that can be empirically tested and may provide the basis for a prediction of outsourcing or non-outsourcing patterns within and between firms (see, e.g. Alewell et al. 2007a). So far, no unambiguous general conclusions about HR outsourcing can be drawn as many differing factors influence the decision process in companies. However, our comprehensive approach fosters the structuring and analysis of the numerous partial effects and makes it easier to evaluate the scope of specific hypotheses about partial effects. Here, detailed theoretical and empirical work will be a necessary element of the further development of the explanatory approach.

\section{References}

Addison, J.T./Surfield, C.J. (2005): ‘Atypical Work' and Compensation. IZA Discussion Paper No. 1477. Adler, P.S. (2003): Making the HR Outsourcing Decision. In: MIT Sloan Management Review, 45 (1): $53-$ 60.

Alewell, D. (2004): Arbeitsteilung und Spezialisierung. In: G. Schreyögg/A. Werder (Eds.): Handwörterbuch Unternehmensführung und Organisation. Stuttgart: Schäffer-Poeschel: 37-45.

Alewell, D./Bähring, K./Canis, A./Thommes, K. (2005a): Determinanten der Nachfrage nach Personaldienstleistungen durch Unternehmen - Überlegungen zur "strukturellen Stimmigkeit" der Personalarbeit. In: H. Lindstädt/T. Spengler (Eds.): Strukturelle Stimmigkeit in der Betriebswirtschaftslehre. München, Mehring: 169 - 192.

Alewell, D./Bähring, K./Hauff, S./Thommes, K. (2007a): Triggers of HR Outsourcing Decisions. Discussion Paper, 16, Collaborative Research Center 580, Jena.

Alewell, D./Bähring, K./Thommes, K. (2005b): Eine Theorie der Nachfrage nach Personaldienstleistungen. Discussion Paper, 1, Collaborative Research Center 580, Jena.

Alewell, D./Bähring, K./Thommes, K. (2007b): Die Wirkungen des Outsourcings von Personalfunktionen - ein Überblick über verschiedene theoretische Ansätze und Entwicklung eines umfassenden Wirkungssets. Forthcoming in: Arbeit, 16 (4).

Ang, S./Cummings, L.L. (1997): Strategic Response to Institutional Influence on Information systems Outsourcing. In: Organization Science, 8 (3): 235-256.

Ang, S./Straub, D.W. (1998): Production and Transaction Economies and IS Outsourcing: A Study of the U.S. Banking Industry. In: MIS Quarterly, 22 (4): 535-552.

Aubert, B.A./Rivard, S./Patry, M. (1996): A Transaction Cost Approach to Outsourcing Behaviour: Some Empirical Evidence. In: Information \& Management, 30 (2): 51-65.

Autor, D.H. (2003): Outsourcing at will: The contribution of unjust dismissal doctrine to the growth of employment outsourcing. In: Journal of Labor Economics, 21 (1): 1-42. 
Bähring, K./Thommes, K. (2007): Kooperation und Konkurrenz in Personaldienstleistungsbeziehungen - Theoretische Überlegungen und explorative Ergebnisse. Forthcoming in: G. Schreyögg/J. Sydow (Eds.): Managementforschung 17, Wiesbaden.

Barney, J.B. (1991): Firm resources and sustained competitive advantage. In: Journal of Management, 17: 99-120.

Belcourt, M. (2006): Outsourcing - The Benefits and Risks. In: Human Resource Management Review, 16 (2): 269-279.

Bruch, H. (1998): Outsourcing: Konzepte und Strategien, Chancen und Risiken. Wiesbaden: Gabler.

Burke, R.J./Ng, E. (2006): The changing nature of work and organizations: Implications for human resource management. In: Human Resource Management Review, 16 (2): 86-94.

Calmfors, L. (2005): Outsourcing, In: Report on the European Economy 2005. European Economic Advisor Group at CES ifo. Munich: 39-50.

Cánez, L.E./Platts, K.W./Probert, D.R. (2000): Developing a Framework for Make-or-Buy Decisions. In: International Journal of Operations \& Product Management, 20 (11): 1313-1330.

Cardon, M.S./Stevens, C.E. (2004): Managing human resources in small organizations: What do we know? In: Human Resource Management Review, 14 (3): 295-323.

Coase, R. (1937): The nature of the Firm. In: Economica, 4: 386 et seq.

Connelly, C.E./Gallagher, D.G. (2006): Independent and dependent contracting: Meaning and implications. In: Human Resource Management Review, 16: 95-106.

Cooke, F.L./Shen, J./McBride, A. (2005): Outsourcing HR as a competitive strategy? A Literature Review and an Assessment of Implications. In: Human Resource Management, 44 (4): 413-432.

Cronin, B./Catchpowle, L./Hall, D. (2004): Outsourcing and Offshoring. In: CESifo Forum 2: 17-21.

David, P.A. (1985): Clio and the Economics of QWERTY. In: American Economic Review, 75 (2): 332337.

DiMaggio, P.J./Powell, W.W. (1983): The iron cage revisited: Institutional isomorphism and collective rationality in organizational fields. In: American Sociological Review, 48: 147-160.

Foote, D.A./Folta, T.B. (2002): Temporary workers as real options. In: Human Resource Management Review, 12: 579-597.

Gainey, T.W./Klaas, B.S. (2003): The Outsourcing of Training and Development: Factors Impacting Client Satisfaction. In: Journal of Management, 29 (2): 207-229.

Gottfredson, M./Puryear, R./Phillips, S. (2005): Strategic Sourcing - From Periphery to the Core. In: Harvard Business Review, 83 (2): 312-139.

Greer, C.R./Youngblood, S.A./Gray, D.A. (1999): Human Resources Management Outsourcing: The Make or Buy Decision. In: The Executive, 13 (3): 85-96.

Grover, V./Cheon, M.J./Teng, J.T.C. (1996): The effect of service quality and partnership on the outsourcing of information systems functions. In: Journal of Management Information Systems, 12 (4): 89-116.

Grund, C. (2006): Selektionseffekte und Vermittlungserfolge privater Arbeitsvermittlung. In: Zeitschrift für betriebswirtschaftliche Forschung, 58: 212-234.

Jack, S./Hyman, J./Osborne, F. (2006): Small entrepreneurial ventures culture, change and the impact on HRM: a critical review. In: Human Resource Management Review, 16 (4): 456-466.

Jenster, P./Petersen, H.S./Plackett, P./Hussey, D. (2005): Outsourcing - Insourcing. Can vendors make money from the new relationship opportunities? Chichester et al.: Wiley.

Klaas, B.S./McClendon, J./Gainey, T.W. (1999): HR Outsourcing and its impact: The Role of transaction costs. In: Personnel Psychology, 52: 113-136.

Klaas, B.S./McClendon, J./Gainey, T.W. (2001): Outsourcing HR: the Impact of Organizational Characteristics. In: Human Resource Management, 40 (2): 125-138.

Klein, P.G. (2004): The Make-or-Buy Decision: Lessons from Empirical Studies. CORI Working Paper, No. 2004-07.

Kossbiel, H. (1990): Personalbereitstellung und Personalführung. In: H. Jacob (Ed.): Allgemeine Betriebswirtschaftslehre. Wiesbaden: Gabler: 1045-1257.

Lacity, M.C./Willcocks, L.P. (1998): An empirical investigation of information technology sourcing practices: lessons from experience. In: MIS Quarterly, 22 (3): 363-408. 
Lawler, E.E. (2005): From human resources management to organizational effectiveness. In: M.R. Losey (Ed.): The future of human resource management: 64 thought leaders explore the critical HR issues of today and tomorrow, Hoboken, NJ et al.: Wiley: 144-152.

Lawler, E.E./Ulrich, D./Fitz-Enz, J./Madden, J.C. (2004): Human Resources Business Process Outsourcing. Transforming How HR Gets Its Work Done. San Francisco, Calif.: Jossey-Bass.

Lepak, D.P./Bartol, K.M./Erhardt, N.L. (2005): A contingency framework for the delivery of HR practices. In: Human Resource Management Review, 15 (2): 139-159.

Lever, S. (1997): An analysis of managerial motivations behind outsourcing practices in Human Resources. In: Human Resource Planning, 20 (2): 37-47.

Marlow, S. (2006): Human resource management in smaller firms: A contradiction in terms? In: Human Resource Management Review, 16 (4): 467-477.

Matiaske, W./Kabst, R. (2002): Outsourcing und Professionalisierung in der Personalarbeit. Eine transaktionskostentheoretisch orientierte Studie. In: W. Nienhüser/A. Martin (Eds.): Neue Formen der Beschäftigung - neue Personalpolitik?, München et al.: Hampp: 247-271.

Matiaske, W./Mellewigt, T. (2002): Motive, Erfolge und Risiken des Outsourcings - Befunde und Defizite der empirischen Outsourcing-Forschung. In: Zeitschrift für Betriebswirtschaft, 72: 641-659.

Mayson, S./Barrett, R. (2006): The "science" and "practise" of HRM in small firms. In: Human Resource Management Review, 16 (4): 447-455.

Meckl, R. (1999): Personalarbeit und Outsourcing. In: R. Meckl (Ed.): Personalarbeit und Outsourcing, Frechen: Datakontext: 7-60.

Mellewigt, T./Kabst, R. (2003): Determinanten des Outsourcings von Personalfunktionen: Eine empirische Untersuchung auf der Basis des Transaktionskostenansatzes und des ressourcenorientierten Ansatzes. Vortragsmanuskript zum Vortrag auf der 65. Wissenschaftlichen Jahrestagung des Verbandes der Hochschullehrer für Betriebswirtschaft, Zürich.

Mummert Consulting (2004): Benchmarking-Studie "Erfolgsmodelle im Outsourcing" April 2004.

Picot, A./Reichwald, R./Wigand, R.T. (2003): Die grenzenlose Unternehmung: Information. Organisation und Management. Wiesbaden: Gabler.

Poppo, L./Zenger, T. (1998): Testing alternative theories of the Firm: Transaction Cost, KnowledgeBased, and Measurement Explanations for Make-or-Buy-Decisions in Information Services. In: Strategic Management Journal, 19 (9): 853-877.

Sayegh, L./Anthony, W.P./Perrewé, P.L. (2004): Managerial decision-making under crisis: The role of emotion in an intuitive decision process. In: Human Resource Management Review, 14 (2): 179199.

Slaughter, S./Ang, S. (1996): Employment outsourcing in information systems. In: Communication of the ACM, 39 (7): 47-54.

Tolbert, P.S./Zucker, L.G. (1996): The Intitutionalization of Institutional Theory. In: S.R. Clegg/C. Hardy/W.R. Nord (Eds.): Handbook of Organization Studies, London: Sage: 175-190.

Vosberg, D. (2002): Der Markt für Personaldienstleistungen - eine theoretische und empirische Analyse. Dissertation, Universität Leipzig.

Walker, G./Weber, D. (1984): A Transaction Cost Approach to Make-or-Buy Decision. In: Administrative Science Quarterly, 29: 373-391.

Wernerfelt, B. (1984): A Resource-Based View of the Firm. In: Strategic Management Journal, 5 (2): 171 180.

Williamson, O.E. (1990): Die ökonomischen Institutionen des Kapitalismus. Unternehmen, Märkte, Kooperationen, Tübingen: Mohr.

Williamson, O.E./Wachter, M. L./Harris, J.E. (1975): Understanding the Employment Relation: Analysis of Idiosyncratic Exchange. In: Bell Journal of Economics, 6 (1): 250-280.

Zucker, G.L. (1991): The Role of Institutionalization in Cultural Persistence. In: P.J. DiMaggio/W.W. Powell (Eds.): The new institutionalism in organizational analysis. Chicago et al.: Univ. of Chicago Press: 83-117. 